\title{
WHITMAN'S LEAVES OF GRASS AND THE WRITING OF A NEW AMERICAN BIBLE
}

\author{
W. C. HARRIS
}

"We too must write Bibles, to unite again the heavens and the earthly world." -Emerson, Representative Men ${ }^{1}$

IN 1857, between the second and third editions of Leaves of Grass, Whitman announced in a notebook his plan for "The Great Construction of the New Bible" (NUPM 1:353). ${ }^{2}$ Like the calendrically referenced lectionary of the Elizabethan Book of Common Prayer (1558), the structure of this prospective Bible- "Three Hundred \& Sixty Five" poems, one for each day of the year-would consist of internal textual divisions after which the life of the reader could be patterned. ${ }^{3}$ Although Whitman says that the "New Bible . . ought to be read[y] in 1859," he makes only one other allusion in the 1850 s to a neo-Biblical project: "Leaves of Grass'-Bible of the New Religion." "Not surprisingly, critics have tended to minimize Whitman's reference to a "New Bible" as little more than a passing conceit, one of several ideas the poet considered as a symbol for the kind of cultural work he was endeavoring to do. The least dismissive accounts concede that if such a neo-Biblical intent manifests itself in any edition of Leaves, it would be the 1860 edition. ${ }^{5}$ But if we weigh the force with which Whitman speaks of a New Bible as "the principal object-the main life work," and if we consider the fact that the mid-nineteenth century was to-date the most active period of sectarian splintering and Bible translation in American history, it seems that an important argument has been left unmade about the way in which the 1860 Leaves responds to demands that nineteenth-century Americans were making on the Bible, the work that sacred writing, in its received and newly invented forms, was being called to do (NUPM 1:353). As Emerson had insisted ten years earlier in Representative Men, "We too must write Bibles, to unite again the heavens and the earthly world."

A New Bible presents an alternative to the sacred but incomplete "covenant of the Republic ... sworn to by Washington ... with his hand upon the Bible," accomplishing what the Revolution had left incomplete. ${ }^{6}$ If Whitman has memorably written that " $[t]$ he United States themselves are essentially the greatest poem," it must not be forgotten 
that in the same preface (1855) he refers to that poem as "the great psalm of the republic," that is, as a sacred poem (PW 2:434, 437; emphasis added). ${ }^{7}$ Recasting Leaves in 1860 as a New Bible allows Whitman to attack the problematic of the one and the many as the central cultural problem for America, not so much to revise the constitutional regime with a religious supplement as to replace it with a new order in which the political is no longer a category, or at least in which the function of the political has been subsumed by a formation both literary and theological in character, a text whose generic complexity implies a discourse of wider, more efficacious authority.

Critically, little has been said about a phenomenon of great interest to any investigation of the constitutional regime in American literature: the writing of a New Bible, the New American Bible. I refer not to one specific text, but to the mid-century deluge of private and institutionally sponsored translations and revisions of the received, Authorized (King James) Version. Idiosyncrasies of translation and redaction aside, these texts are all "new Bibles": foundational texts that constitute a protocol of relation divergent from, and meant to usurp the institutional status of, that of extant secular and/or religious documents. Within this context, the 1860 edition of Leaves, which is the next edition after the 1857 notebook entry planning "the New Bible," appears to be one such essay at an American Bible, a document intended to found a new, scripturally based social formation.

Understanding what Whitman means by a "New Bible" and what it means to read the 1860 Leaves as such requires some understanding of what the Bible itself meant both to Whitman and to American culture at large in the mid-nineteenth century. Many Americans turned to the Bible and to religion in the hopes of accomplishing the work at which secular texts and institutions were failing: the reconstruction of relations on an unmediated or egalitarian basis, either textual or sectarian. Yet the character of new religious sects and communities formed between 1830 and 1850 (including Mormonism, Oneidan perfectionism, and Seventh-Day Adventism) must be differentiated from those which had gone before. ${ }^{8}$ By the 1840 s the de-authorization of the King James Version was almost a fait accompli: German-born Higher Criticism had discredited the Authorized Version's claims to historical accuracy, and the number of private translations was growing exponentially. The decades following the Second Great Awakening saw the decline of America's established or predominant religion (first Congregationalism, then Unitarianism) and the rise in prominence and membership of previously minor sects (Methodists, Baptists, and Disciples of Christ). Thus, while theological authority had come to seem, at least to Whitman, incompatible with the hierarchical and dogmatic character of institutions, it nonetheless appeared impossible to distribute identity without some 
structural or creedal basis. Paradoxically, the multiplication of sects (and thus of claims of a privileged relation to a transcendent term) which had drawn the status of the transcendent term into doubt also rendered its reconstruction more critical.

Redeeming the unrepresented may be Whitman's chief poetic and political objective. But that objective requires the redemption of something more dubious, problematic, and perhaps unattainable: theological authority. Whitman is fully aware of the various institutional causes in which theology has been enlisted, "the paraphernatia ? of modern worship, [the] sects, churches, creeds, pews, sermons, [and] observances ... [that] have nothing to do with real religion" (NUPM 6:2091-2092). But just as the Disciples of Christ cast off ecclesiastical doxa in favor of sola scriptura ("the Bible alone"), so does Whitman reject institutional attempts to regulate the relation of the many to the one. This is not to say that mediation can be dispensed with: when the poet writes that "what passes as the authority of the Bible...[must] surely, surely go," his objection is not to mediation per se but rather to the restriction of the right to mediate to one text, the Authorized Version (NUPM 6:2091). Thus while theological authority should be disestablished, Whitman asserts just as strongly that it cannot exist outside some social or literary formation (a nation or a poem) that distributes it. "The people," he writes in the 1872 Preface,

must begin to learn that religion, (like poetry,) is something far, far different from what they supposed. It is, indeed, too important to the power and perpetuity of the New World to be consign'd any longer to the churches, old or new, Catholic or ProtestantSaint this, or Saint that. It must be consign'd henceforth to democracy en masse, and to literature. It must enter into the poem of the nation. It must make the nation. ( $P W 2$ : $462-463)^{9}$

For Whitman poetry has the power to "make the nation." But the redemption of theological authority without mediation seems virtually impossible. When in the 1855 Preface Whitman declares categorically that " $[t]$ here will soon be no more priests" to mediate the individual's relation to the divine, he immediately qualifies the revolutionary force of his words by adding, "A new order shall arise" and "take ... [the priests'] place": "they shall be the priests of man, and every man shall be his own priest. The churches built under their umbrage shall be the churches of men and women. Through the divinity of themselves shall the kosmos and the new breed of poets be interpreters of men and women and of all events and things." 10 The centrality of this paradox to Whitman's project-the mediation of non-restricted identity-is captured in his perhaps most well-known apothegm, from Democratic Vistas : "The priest departs, the divine literatus comes" (PW 2:365)."

The question, though, is whether sacerdotal functions can be assumed without the more negative consequences of institutionalization, 
whether a priesthood of men and women, no matter how inclusive its congregation, does not still constitute a hierarchy. ${ }^{12}$ Whitman's answer may be paraphrased as "yes, but it cannot be helped." The advancement made by the 1860 Leaves of Grass is the realization that the mediatory structures necessary to the unification of disparates do not have to negate the value or scope of the new social identity being distributed. For Whitman, the new religion is to be an institution which is not an institution, meaning that it is not administered by an invested few, a class administering its own hierarchical distinction. Whitman expresses this paradox most succinctly in an 1857 notebook entry, "Founding a new American / Religion (? No Religion)," that is, a religion that is no religion, a rite that is practicable without being regulated (NUPM 6: 2046). ${ }^{13}$ What Whitman attempts to forge with his New Bible is a protocol of relation that hovers between being an actualized and a purely theoretical state of affairs. Whitman may adopt an ambivalent stance toward formalization, rejecting all sectarian, doctrinal restrictions; still, the new housing of religion - whether nation-as-poem or poetry-as-Scripture-cannot escape its own creedal (and therefore mediatory) status. After looking more closely at the wider cultural project of the New Bible, I want to conclude by turning to "So Long!"- the last poem in the 1860 edition - as an experiment in the modeling of the commensurability of persons on the basis of less costly incommensurabilities: the sacrifice of immediacy, intranslatability, and silence for moments of mediation, translation, and a comprehensible social presence. "So Long!" suggests that free, open, unmediated relation is available, paradoxically, only by way of mediation, by disruption and fragmentation-only by admitting hierarchy as being on some level ineluctable, as that which must intrude upon any social or institutional reality.

Whitman was not the only American who found it necessary, either by revising the Authorized Version (the King James Version) or by writing an entirely new Bible, to produce an American Bible and so claim the United States, the New Israel, as the site upon which old covenantsBiblical as well as federal-would be fulfilled. The unprecedented formation of new religious sects between 1830 and 1850, most of which claimed an idiosyncratic understanding of Scripture not mediated by dogma, contributed significantly to the decentering of the Authorized Version and, consequently, to the democratization of the transcendental term. For those who chose to produce new Bibles, the greatest difficulty was distribution - both in the literal sense of distributing multiple copies of a uniform, foundational text and in the symbolic sense of translating, of making one text (whether the Authorized Version or not) speak to its many readers. In Whitman's hands, the ambiguous strategies of 
translation and distribution are the means for constructing a distributive model of social identity which is capable of evading the mediatory effect of institutions.

American Bible translation, revision, and distribution, all of which reached an unmatched peak in the mid- $1800 \mathrm{~s}$, provided a concrete means of re-theorizing social order by creating a new community, the identity of which was mediated through a single (and often unique) document, so that the value of persons and the physical text itself transcended existing distinctions between states, races, classes, and sects. Before 1816, the year the American Bible Society (ABS) was founded in New York, the distribution of Bibles on a wide scale had been unknown. Any group distributing Bibles up to that point had done so on a local level and with limited means. As a national organization with corporate means, the ABS began to find it possible to realize what Peter Wosh refers to as the "fundamentally new idea" of "Christianiz[ing] the nation." 14 In just four years, the ABS printed and distributed 100,000 Bibles. Over the next four decades, as the Society sought to reach (or rather, create) a nationwide market, Bible recipients came to include immigrants, Confederate soldiers, and slaves. The sole criterion for admission to this new polity was the possession of a Bible. Equality was as available as a book; the resultant union, without limit-and, for once, without differentiation. ${ }^{15}$

A great part of the impetus for Bible distribution campaigns was the dramatic increase of interest in Bible translation. One cannot overemphasize how remarkable it was that, suddenly, so many people found it necessary, if not imperative, to make new translations of a text that had been accepted in one standard, authorized form - the King James Version (1611) - for over two hundred years. Furthermore, it was not just clerics and academics but lay believers who were calling for and executing new translations. What was being produced were not just scholarly, officially endorsed refinements of a master-text, or revisions meant to produce a more authentic and accurate translation. The trend was increasingly toward sectarian and idiosyncratic revisions and re-translations, emphatically private versions of a Bible believers came to see as that much more their own Bible. ${ }^{16}$ The implications of this trend for social formation are obvious: total fragmentation; individual autonomy valued at the expense of the unity of not only the state but, very often, the sect that a new version was intended to found or establish. But, as a particularly striking episode in Bible translation history shows, translation, like distribution, is potentially as unifying as it is divisive.

In 1826 Alexander Campbell, who had founded the Disciples of Christ fifteen years earlier, published a version of the Bible intended to correct and update the language of the King James Version (KJV). One of the changes he made ignited a controversv that would last for over 
forty years. That change was the substitution, in the New Testament, of the word immerse for the word baptize. Campbell bases the alteration on the fact that the words baptize and baptism, which appear in the KJV, are not translations of the original Greek words, baptizo and baptizein, but rather transliterations. The source of what Campbell views as an error is the second-century Latin translation of the Septuagint, which transliterates baptizo into "baptize" instead of using the closest Latin equivalent (immergere, to immerse). ${ }^{17}$ Linguistic accuracy aside, using "immersion" appealed to Campbell's nonsectarian instincts by avoiding any exclusive, denominational privilege "baptism" might be taken to lend to Baptists. In the next thirty years, at least eight English immersionist versions and foreign-language translations of the KJV followed suit, inciting both enthusiasm and outrage. In 1835 the ABS refused to print Bibles for Baptist missionaries in Calcutta who, faced with a language that lacked an equivalent for "baptize," had used the Bengali word for "immerse" rather than transliterate baptizo. Those within the ABS who had been outvoted on the matter, led by Spencer Cone and William Wyckoff, split off in 1836 to form the American and Foreign Bible Society (AFBS). Although formed by pro-immersionists, the AFBS soon became divided between those who favored the practice in foreign translations only and those who wanted to do so only in English. The latter faction, led again by Cone and Wyckoff, broke off in 1850 to start a third organization, the American Bible Union, which published the longawaited immersionist version (of the New Testament, at least) in 18621863. Matthew Conant's 107-page Appendix to his translation of Matthew demonstrates the length to which immersionists would go, the fervor that had brought them this far. Both immersionists and their opponents deeply appreciated the impact of single words: the implications of translation, the ability of textual changes to create or dissolve communities and societies. ${ }^{18}$ Anti-immersionist Baptists claimed they rejected the practice because it was sectarian, but it seems clear that they themselves were acting out of sectarian interests.

What the immersionist controversy did for Whitman and his contemporaries was to intensify the problems facing any religious or social formation committed on the one hand to unity (to the idea of one God or one state) and on the other hand to equality (the acceptance of multiple interpretations of that God or state). One problem is that the distribution of identity on an unrestricted basis can be accomplished only through some form of mediation (a New Bible, in this case). In other words, the immediacy hoped for in a more open model of relation will always be qualified simply by being implemented, by the differences that bodies and texts inevitably bring with them. ${ }^{19}$ The lesson Whitman might be said to have taken away from the tribulations of American Bible societies is the difficult yet important task of coming to terms with the exact nature of institutions. The great discovery of the 1860 Leaves 
is that the success of any prospective social formation in producing unity or distributing identity rests upon its ability to negotiate the inherently hierarchical character of representation itself. To overcome hierarchy, relation would somehow have to defy its own mediatory, static character. Alexander Campbell's sect, the Disciples of Christ, was initially dedicated to the merging of all Christian sects in a single, nondenominational form-dedicated, that is, to its own eradication. If the new American religion is to be anything like the new American social formation, that is, an institution that eschews hierarchy, then a model founded on self-refuting claims is ideal; its frangibility would render it capable of generating a structure which is not only open to but also capable of its own revision. In this way, Whitman's "new American Religion" evades stratification and restriction of access even as habits of relation are implemented and generalized; it is capable always of collapsing back onto itself, of re-initiating and refounding itself like the American Bible Society, thereby harnessing both the strength of an established structure and the openness of a praxis just being forged. The New Bible is the central element of Whitman's plan for a new religion, an entirely new theologically grounded institution that, with its own priesthood and sacred text, proposes, counterintuitively, to mediate unmediated discourse.

The means by which Whitman attempts to satisfy this paradoxical objective are also the terms by which he represents its constitutive tension. As in the immersionist controversy, the tension between unity and differentiation is played out in the inclusive and exclusive practices of religious communities-the former represented by immersion, or the dissolution of particulars into a nondifferentiated whole, and the latter by baptism, or the crystallization of one out of the many into a discrete body or sect. The immersionist impulse of Leaves is familiar from the heart-tongue kiss in "Song of Myself," Section 5. It is true that Whitman retains this impulse: "So Long!" (1860) contains similar moments of realized immediacy, or immersion, moments in which the obstacles to absolute unity (like bodies and institutions) are dissolved. But, by contrast with "Song," "So Long!" sets these moments in opposition to others in which the experience of oneness is mediated, translated, made legible and vocal so that it can be made available and can be distributed to the members of this New Bible's congregation. Translation and distribution, which served as much as they disrupted the objectives of Bible societies and sectarians, are deployed by Whitman as the ideal kind of mediation, a self-canceling form of hierarchy that builds a non-institutional, immediate unity that need not be spoken (the sub-vocal "hum" of "Song") on the disparities, the distances across which oneness must be translated, made available in writing to those who, not being one, do not already know it ( $L G 33$ ). By concluding the 1860 edition with "So Long!," Whitman literally leaves us with the idea that it is only by the 
sacrifice of unity that unity can be actualized at all. By accepting translation over against immediacy, baptism over against immersion, and hierarchy over against equality, the poet of "So Long!" comes to understand that the latter term of each pair exists only in relation to the other, only within the whole that comprises them both.

As the last poem of the 1860 edition, as well as the next four editions, "So Long!" has the authority of being the last word. Yet it is not, perforce, a poem of "conclusion": "To conclude-I announce what comes after me, / The thought that must be promulged, that all I know at any time suffices for that time only-not subsequent time; / I announce greater offspring, orators, days, and then depart."20 For the most part, this poem is a re-writing of organic death as symbolic life: ending as beginning, death as birth, disruption as continuity. Unlike the instant transformation of discourse and self achieved in Section 5 of "Song of Myself," the exchange of mediation for immanence is here neither certain nor instantaneous. The reward may not follow hard on the sacrifice, if it does at all. The sacrifice required may be ongoing. This time, shedding the difference of bodies does not render persons unequivocally accessible:

Dear friend, whoever you are, here, take this kiss,

I give it especially to you-Do not forget me,

I feel like one who has done his work-I progress on,

The unknown sphere, more real than I dreamed, more direct, darts awakening rays about me-So long!

Remember my words - I may again return - I love you-I depart from materials, I am as one disembodied, triumphant, dead. ${ }^{21}$

"I am as one disembodied, triumphant, dead" implies that a disembodied Whitman will be present to each reader of Leaves of Grass, in the book itself. But his presence in the text is not assured; he speaks like an ascending Christ who promises no Paraclete or Comforter, or does so only equivocally: "Remember my words-I may again return-I love you-I depart from materials." The phrase "Death making me undying" describes a state of affairs in which an intelligible, mediated state has been traded for a less than or barely intelligible one, one that borders between the unmediated (the only register in which meaning can be made available to everyone) and the mediated (the only register in which sense can be made to anyone).

The most perplexing movement in this poem-and, in its occurrences here and elsewhere in Whitman's oeuvre, a common subject in the criticism ${ }^{22}$-is that by which Whitman is "disembodied, triumphant, dead" and yet re-embodied in the book before us. Although familiar to most readers of Whitman, the gesture is perhaps misunderstood. The lines "My songs cease-I abandon them, / From behind the screen where I hid, I advance personally" summon up that moment in "Song of $\mathrm{My}$ - 
self," Section 6, when the poet assures us with the image of interred bodies growing up from the graves into living grass that "there is really no death," that death makes no difference. ${ }^{23}$ "So Long!" makes the more nuanced argument that death, in fact, makes all the difference, that, even though death takes much (it interrupts the familiar, transposing or translating it into a foreign tongue), the potential returns for persons and social formations are immense (it equalizes, it unites across difference) ${ }^{24}$ When Whitman claims in "So Long!" to come out "[f]rom behind the screen," that disclosure has the same self-mitigating force as the claim to "advance personally" (or, as Whitman would later intensify the line, "advance personally solely to you" [ $L G 505$, emphasis added]). Just as the poet claims to make the person immanent but must do so through textual mediation, so does the privileging of the reader who "solely" receives Whitman's "advance" undo itself by extending that privilege to anyone who reads this poem. Translation holds a no less complicated status, since what the poet makes available to each reader"curious enveloped messages"-he does so "personally," in "whispers" that we must "ben[d] for" and decipher in our personal, non-linguistic vocabularies ("My songs cease"). Translation allows communication across difference, but, as a kind of death (as in "old age ... meet[s] its translation"), it entails the canceling out of the original text and the possible loss of meaning: "So long! / I announce a life that shall be copious, vehement, spiritual, bold, / I announce an old age that shall lightly and joyfully meet its translation." 25

This brings us to what I take to be the import of "So Long!": Translation is perhaps the only way we can be one. As a species of mediation, translation risks error (either willful or unintentional); it involves fragmentation, the breaking down of a compositional whole, so that, as a collection of analogous fragments, the whole may eventually be transmitted. Yet translation only brackets the issue of incommensurability. The second-language version is always an approximation of the original text, and yet, unless we learn that second language, we must accept translation as being more or less commensurable to the original. ${ }^{26}$ In the case of the unrestricted relation of persons, or the integration of the many into the one, we do not have the option of learning a second language. In unity, there is no language; in plurality, there are too many languages. We must parse out unity in so many moments of broken speech. Whitman has not said we will all understand, or that we will understand at once. When we do, however, the reward is substantial enough to keep us reading, to continue attempting to translate.

In opposition to the word "translation" in "So Long!" stands the word "immerged," for it is between these poles that Whitman syspends his "true theory of the youth, manhood, womanhood, of The States," his theorization of social formation and its potential for immanent change. ${ }^{27}$ Although Whitman uses the word immerge instead of immerse, 
any substantive difference between these two words which come from the same Latin verb (immergere; past participle, immersus) seems negligible. For Whitman, immersion connotes absorption (cf. $L G 43$, line 299; and $L G 166$, line 10) and the erasure of the particularizing, sectarian marks that baptism confers in his lexicon (cf. $L G 236$, line 18; and $L G$ 299, line 108). One meaning of "immersion" is "baptism," however, and it is on this connection, contested so fiercely among Bible societies, that Whitman plots the volatile course of social formation:

O how your fingers drowse me!

Your breath falls around me like dew-your pulse lulls the tympans of my ears, I feel immerged from head to foot,

Delicious-enough. ${ }^{28}$

"[I]mmerged from head to foot" evokes its predecessor-image in "Song of Myself" ("[you] reach'd till you felt my beard, and reach'd till you held my feet" [ $L G 33])$. The consummative moment of the earlier poem is simultaneously embraced and stayed, as the ambiguous "Deliciousenough" implies. Immediacy is at once "enough" and insufficient, because the message is immanent but its meaning is far from clear (or, on the other hand, because the meaning is immanent and the message capable of transmitting it, garbled or lost).

More than a fantasy about his posthumous reception and fame or a critique of the relation of the author's corpus (both his text and his person) to the market, "So Long!" presents us with an equality-based model of relation but can only do so by deferring complete fulfillment, translating some fraction of that equality into another, immediately inaccessible register. That is the difference which death reinstates, the mediation that unrestricted relation invokes, which it must invoke to stave off differentiation and the proliferation of hierarchy. Whitman presents us with a discourse that does not simply maintain itself over time by deferral and incommensurability but is sustained by its own interruption, its translation into registers that are never quite coincident.

The idea of translation brings us again to what must remain the central criterological question for a New Bible: what kind of Bible is it to be, compared with its predecessor texts? If the 1860 Leaves is to be regarded as one such New Bible, the question then becomes, How is Whitman's intent specifically neo-Biblical? As the beleaguered history of American Bible societies suggests (and as the title of Peter Wosh's study of the ABS emphasizes), "spreading the word" was the order of the day for poets like Whitman as well as for minister-scholars like Alexander Campbell, Spencer Cone, William Wyckoff, and Thomas Conant. The phrase distributing the word (by which I mean not just the logistics of doing so but the implications of having done so) serves to name a culturally active problematic in mid-nineteenth century America, 
the answer to which was sought by poets, ministers, and illuminists, through new books, sects, and religions. All of these individuals asked, How does one unite a community? How does one do so with one text, with a text that is individual for each yet possesses some consistent core for all? The New Bible is the salient model for the third edition of Leaves not simply because in 1857 Whitman writes that it is, but rather because in 1860 he takes this problematic to the extreme. Everyone's not having the same text-or having one that shifts between the legible and the inscrutable, between the "emblematic" 29 and the real-is the fons et origo of the self-refuting institution capable of its own continual re-theorization. Whitman's New Bible invokes an institution that is as nonhierarchical and unrestricted as relation ever can be because it is so intermittently. ${ }^{30}$

In "So Long!" Whitman himself is translated, as if he is the text. $\mathrm{He}$ is translated not into a language but rather into another representational space. As soon as he announces "an old age that shall lightly and joyfully meet its translation," he says, as if surprised, "It appears to me that I am dying." " Far from holding off his own translation as he had in the 1855 Leaves ("I too am untranslatable"), he greets translation as the movement into another tongue, another register, in which the gain cannot be communicated precisely but is known by the loss that accompanies it ("Song of Myself," LG 89). Since my interpretation of "So Long!" depends on the notion of "translation," which I connect to the various translations of the Bible, I should make it clear that my reading is not meant to elide the fact that the "translation" that "old age" meets in verse 14 is death, a translation of the self or consciousness from the material to the spiritual world. But, given the ways in which Whitman marks the 1860 edition as neo-Biblical (for instance, dividing the text into enumerated sentences, not sections or stanzas), I believe that "translation" should also be read as referring to a linguistic change. I do not regard these two senses of "translation" as interchangeable, nor does Whitman; but he wants to be able to do so. My reading draws attention to the way in which Whitman means to render books and bodies, if not interchangeable, then communicable, the way in which he regards words and selves as things that are, to common sense, not commensurable, yet whose very incommensurability demands an economy of exchange, a distributive logic, whose currency is grounded on frangibility, fragmentation, interruption - those breaks which are really what permits transmission, what allows something to come across. Any slippage in meaning, then, between the two kinds of "translation" is one upon which Whitman depends. ${ }^{32}$

The fact that this book before us is "no book, / . . [but] a man" reinforces the sense in which translation is death and continuation, revelation ("From behind the screen where I hid, I advance") and obfuscation ("enveloped messages"; "immerged from head to foot"). "[D]ecease 
calls me forth" - both to us, the readers, and away from us, toward some unknown. ${ }^{33}$ Leaves of Grass is still a book of poetry. We can decipher some of it; some parts remains obscure. But we are left to parse it on our own, in a dyadic congregation that links us, tenuously, to others working at the same text, if not with the same purpose. Leaves is part of the writing of the New Bible, not necessarily the final product itself. As Whitman wrote in the 1860 poem "Says" (a poem excluded from Leaves altogether after 1876), the "glory of These States [is] that they respectfully listen to propositions, reforms, fresh views and doctrines, from successions of men and women, / Each age with its own growth." 34 Only three years later, the war would offer Whitman the opportunity while nursing wounded and dying soldiers to practice such an economy, in which loss is accepted in lieu of a value-bearing gain to follow. However, the increasingly unilateral investment of the post-war editions-in the transcendent soul alone, forsaking immanent materiality-suggests that Whitman either found that practice too demanding or found no such reward awaiting him in the Union's victory and its half-hearted Reconstruction.

The outlook, even so, is not as bleak as it may seem. Even though the Whitmanian lesson of personhood must be mediated if we are to receive it, the "mediums" specified in the 1860 Leaves are potentially numerous enough to cease being mediatory. As Whitman prophesies in "Chants Democratic" (1860), they are not only the priest-poets of America but also those they reach with their words, who become poets in their turn: "Strong and sweet shall their tongues be .../ Of them, and of their works, shall emerge divine conveyers, to convey gospels, / Characters, events, retrospections, shall be conveyed in gospels-Trees, animals, waters, shall be conveyed, / Death, the future, the invisible faith, shall all be conveyed." 35 The 1860 edition means, then, to spawn a literature ("divine conveyers," "gospels") that is also a distributive organization, the latter being as ephemeral as it is recurrent, as successful as it is delayed and indirect.

\section{The fohns Hopkins University}

\section{NOTES}

I am grateful to Marsha Fausti, Ed Folsom, Allen Grossman, Judith Harris, Michael Moon, Geoffrey Sill, Larzer Ziff, and the $W W Q R$ readers for commenting on previous drafts of this essay and, through their questions and advice, contributing significantly to its development. I would also like to thank the organizers of The Many Cultures of Walt Whitman conference (Rutgers University-Camden, October 1998), at which I delivered an earlier version of this essay.

1 Ralph Waldo Emerson, Representative Men, Chapter 7 ("Goethe; or, the Writer"), in Essays and Lectures, ed. Joel Porte (New York: Library of America, 1983), 761. Writing new Bibles was not the fixation solely of Whitman or of sectarians and religious visionaries (see Lawrence Buell, New England Literary Culture: From Revolution 
through Renaissance [Cambridge: Cambridge University Press, 1986], 167-168). In Chapter 5 of Representative Men ("Shakespeare; or, the Poet"), Emerson writes that the "world still wants its poet-priest, a reconciler"; Chapter 7, from which my epigraph derives, ends with the following prescription: "The secret of genius is to suffer no fiction to exist for us; to realize all that we know; in the high refinement of modern life, in arts, in sciences, in books, in men, to exact good faith, reality, and a purpose; and first, last, midst, and without end, to honor every truth by use" (Essays and Lectures, 726, 761). As an attempt to realize the unmediated discourse of "Song of Myself" on a larger textual and social scale, the 1860 Leaves seeks to "honor" the truth of the American project "by use," by rendering that truth in its avatars (social and political equality, religious immediacy) usable and practicable. Also to the point is Herwig Friedl's remark that Leaves "contains history in the attempts at symbolic interpretation of the universal process both as sacred or metaphysical and as profane history" ("Making It Cohere: Walt Whitman's Idea of History," Amerikastudien 28 (1983), 295-307; 299.

2 Walt Whitman, Notebooks and Unpublished Prose Manuscripts, ed. Edward Grier (New York University Press, 1984). All further references to the notebooks are marked NUPM and referenced by volume and page number.

3 In Disseminating Whitman: Revision and Corporeality in Leaves of Grass (Cambridge: Harvard University Press, 1991), Michael Moon adds that Whitman's choice of 365 as the number of poems in his New Bible is central to his dedication to "annularity, [that is, to] the making of a great ring or cycle of poems that would have the status of scriptural texts" (124). Thus the calendrical dimension of Whitman's "New Bible "the stipulation of one poem for each day of the year-renders it both atavistic and non-traditional, suggesting that Whitman's Bible comes not only with an improved format but with a prior claim to legitimacy. Another Biblical or liturgical characteristic of the 1860 edition is the numbering not of lines or sections but of individual sentences. For instance, in the 1860 edition the originally undivided "Song of Myself" (which finally ended up in fifty-two sections) was divided into 372 sections, or more exactly 372 sentences, which contain anywhere from one to twenty lines. Furthermore, the marginal enumeration of stanzas in the third edition reads less as a literary effect than a reference aid of the kind found in modern Bibles, here designating the verses of Whitman's New Bible. Moon reminds us that the 1860 text's claim of priority ought also to be understood in relation to Whitman's own work, establishing "a kind of primacy for the third edition which he now wants to deny to the two previous editions, by belatedly deciding that the earlier editions were more tentative ("published . . . on trial') and 'inchoate[ ]' projects than they had actually been" (125).

4 Whitman, Notes and Fragments Left by Walt Whitman, ed. Richard Maurice Bucke (London and Ontario: A. Talbot and Co., 1899), 55.

5 David Reynolds categorizes the "New Bible" as one of several ideas Whitman considered but never pursued while "floundering" for a "metaphor" to unite his book and characterize the kind of serious cultural work it was endeavoring to do (Walt Whitman's America: A Cultural Biography [New York: Knopf, 1995], 368). Reynolds rightly argues that the final words of the 1857 notebook entry ("it ought to be read[y] in 1859") suggest that Whitman "expected the project would be done in two years. Presumably he expected to have completed by then 365 poems, largely of a religious or philosophical nature, to replace or complement the Bible. Although composing new 'Bibles' was not unusual in the era of The Book of Mormon and The Great Harmonia, it is surprising that Whitman would mention such a grandiose project and then drop it-unless the 1860 edition of Leaves of Grass, containing many new religious poems, can be seen as a kind of Bible" (367-368). Reynolds, however, fails to pursue the neo-Biblical argu- 
ment, perhaps because even to him the evidence he cites for it-Whitman's enthusiastic review of Harper's Illustrated Bible (1846) and the decorative illustrations and ornate fonts of the 1860 Leaves - seems at best circumstantial. As I have already pointed out, Leaves bears a number of superficial Biblical characteristics, but it is possible to launch a much stronger argument for Whitman's neo-Biblical intention if we move beyond superficial similarities to affinities of motive and institutional intent.

Only a handful of critics have taken the neo-Biblical claim further than Reynolds. Michael Moon agrees that while Whitman seems by 1860 to have left off constructing a New Bible, "the scriptural ambitions he had first articulated for his project in 1857 account for some of the most significant differences between the 1860 Leaves and its two predecessor-editions" (124). Although, Moon admits, Whitman was "far from unique in cherishing scriptural ambitions for his writing," Whitman, unlike Harriet Beecher Stowe and Julia Ward Howe, did not seek to "tak[e] over such fundamental aspects of Judeo-Christian scriptural tradition as its pervasive soteriological or apocalyptic claims" (124n). My reading of the 1860 edition does not so much contest Moon's reading as it means to sharpen the terms and context of what Moon regards as Whitman's "attempt [ ] to launch a gospel of immanence grounded in the text's extensive interrogations of the natural and the real" $(124 n)$.

Along with Reynolds and Moon, Maria Anita Stefanelli is one of the few critics to deal substantively with the neo-Scriptural motive of Whitman's work ("'Chants' as 'Psalms for a New Bible,"' Utopia in the present tense: Walt Whitman and the language of the New World, International Conference on Walt Whitman, University of Macerata, October 29-30, 1992 [Rome: Calano, 1994], 171-188). Her deManian reading of chiasmus in the "Children of Adam" poems and Psalms 4 and 23 makes the same general point as work by Karen Sánchez-Eppler ("To Stand Between: A Political Perspective on Whitman's Poetics of Merger and Embodiment," ELH 56 [1989], 923949) and Mark Maslan ("Whitman and His Doubles: Division and Union in Leaves of Grass and Its Critics," American Literary History 6 [1994], 119-139). Although Maslan's and Sánchez-Eppler's concerns are more strictly political and formal, my reading is consonant with theirs in contending that "division [as well as union] is a vital principle of Whitman's poetics," one that is "enabling rather than debilitating" (Maslan 136). (See also Herwig Friedl as to how Whitman's attempt to "make a meaningful [that is, a social, cosmic] whole" and yet "find symbols for a totality of change" ends up "creat[ing] the contradictions it sets out to overcome" [306].) Although Stefanelli takes as her starting point F. O. Matthiessen's claim that Whitman "seemed to think that he could gain universality by making his chants psalms for a new Bible," she fails to develop an explanation of what a new Bible might have meant to Whitman and to an audience for whom the founding of new sects and religions came to seem both the answer to the problem of unrestricted relation and no answer at all (Matthiessen, American Renaissance: Art and Expression in the Age of Emerson and Whitman [New York: Oxford University Press, 1941], 557).

6 Whitman, “The Eighteenth Presidency!” (1856), Complete Poetry and Collected Prose, ed. Justin Kaplan (New York: Library of America, 1982), 1307-1325; 1319. Whitman's relation to the founding documents is at once supplementary and foundational. $\mathrm{He}$ regards the Constitution as "a perfect and entire thing, and edifice put together," complete in itself, but also as something which "time only is great enough to give ... area," which can be "better understood from results, growths," supplements and revisions (1318). As a New Bible, Leaves implicitly eclipses the received Scriptures by accommodating present circumstances, by satisfying the need for a text that has an efficacious relation to the state, in a way the Authorized Version cannot (its authority having been bracketed by America's secular founding instruments). By addressing in this new Bible the originary site of state formation, Leaves professes a presence at the 
origins both of the state and of a transcendental, natural state (the site of relation not yet codified by either secular or theological institutions).

7 Whitman, "Preface, 1855, to First Issue of Leaves of Grass," Prose Works 1892, ed. Floyd Stovall, 2 vols. (New York: New York University Press, 1963-1964). All further references to this edition are marked $P W$.

8 American sects had certainly been formed before 1830 , the most prominent being Ann Lee's Shakers (1774) and Alexander Campbell's Disciples of Christ (1811). But nothing could match the fervor with which new sects and new religions arose between 1830 and 1850: Mormonism (1830), Oneidan perfectionism (1838), Jehovah's Witnesses (1844), Seventh-Day Adventism (1844), and Harmonialism (1847)—not to mention a number of Protestant splinter-groups (among them, "Two-Seed" Baptism and Universalism). I am stressing here what I perceive to be the missing subtext of the conventional history of the Bible and social reform in America during the first half of the nineteenth-century (a history recounted by Mark Noll, $A$ History of Christianity in the United States and Canada [Grand Rapids: William B. Eerdmans, 1992]; and Timothy Smith, "Righteousness and Hope: Christian Holiness and the Millennial Vision in America, 1800-1900," American Quarterly 31 [Spring 1979], 22-45). Although the Bible may have adequately funded the state for many Americans, the mid-century welter of new religions and sects suggests that for an equally significant number the same was not true. In his farewell sermon, “The Lord's Supper," Emerson voiced his dissatisfaction in 1832 with established American religion (Congregationalism in his case) and its prescriptive, spiritually empty rituals (Essays and Lectures, 1129-1140). Joseph Smith broke away from his Universalist roots to found Mormonism in $\mathbf{1 8 3 0}$. At the same time, evangelists and theologians like Charles Finney and William Ellery Channing were cutting denominational ties (with Presbyterianism and Congregationalism) in favor of revivals and new sects (for Channing, Unitarianism) that promised a relation to God unmediated by dogma or ecclesiasticism. Thus, although the term post-theological crisis may not refer necessarily to a uniform phenomenon, it seems to me the best term to describe the period of American religious life during which the "individualization of conscience" fostered by the Second Great Awakening (17951810) manifested itself not merely in idiosyncratic Biblical interpretations but in more ambitious projects for the re-grounding of American social formation on neo-Biblical or on literary bases (Nathan O. Hatch and Mark A. Noll, The Bible in America: Essays in Cultural History [New York: Oxford University Press, 1982], 66).

9 Whitman, "Preface, 1872, to 'As A Strong Bird on Pinions Free." Although written after what one might call Whitman's neo-Biblical period (1857-1865), the 1872 Preface is consistent, on this account at least, with notebook entries of the late $1850 \mathrm{~s}$ and the 1860s (see NUPM 6:2061).

10 Whitman, Leaves of Grass, Comprehensive Reader's Edition, ed. Harold W. Blodgett and Sculley Bradley (1965), 729. All further references to this edition are marked $L G$. This passage is notable for the vacillation between "every man['s] . . . be [ing] his own priest" and a select number of individuals (poets) fulfilling that function for them. Similarly, one of Whitman's notebook entries (dated 1857 or after) admits that as soon as the old churches are razed, a new one is immediately erected. It seems that even a religion "comprehensive enough to include all the Doctrines \& Sects" cannot be formed except as a sect, distinguished, if by nothing else, by its willingness to countenance what other sects will not: heterogeneitv (NUPM 6:2046).

11 Although Democratic Vistas in its present form was not published until 1870 (falsely dated 1871), the essays from which Whitman composed this longer piece ("Democracy" and "Personalism") had already appeared in Galaxy, in 1867 and 1868 respectively. 
12 A notebook entry from the 1860 s instantiates this ambivalence between founding a more inclusive religious institution and the impossibility of doing so other than in a congregation, between persons, and therefore within a network of mediating differences: "religion... [must] adjust itself to the ranges of real life and all men and women[.] That would be a religion of some account . . . [namely, one with] reference . . . to ... . the people[.] The people! none excluded-not the ignorant, not roughs or laboring persons-even prostitutes. . . This is what America is for-to justify this is what she means-If not she means nothing. . . . I will not be fooled with the facade of the few ... I say that a religion which from those vast ranges of life in the great cities, raises its house aloof, an exile-which, to them, enters not, and they enter not into it . . . is no religion for These athletic and living States" (NUPM 6:2092-2093). Whitman may not be fooled by the "facade of the few," the structural gradations that admit only a select number into the visibility of a social formation, but, considering the analogy, neither is he fooled by the facade of the many-for the latter is still a facade. Any group, whether of the few or the many, must "raise its house"; and, since even a onestory house must have a floor, walls, and a roof, any blueprint must differentiate to this minimal degree.

13 Though the entry is undated, Grier concludes that "the date, from the paper, is 1857 or after" (NUPM 6:2046n).

14 Peter J. Wosh, Spreading the Word: The Bible Business in Nineteenth-Century America (Ithaca: Cornell University Press, 1994), 64.

15 It is true that in some aspects, the directors of the ABS, like the Federalists, demanded centralization: focal Bible societies were expected, like states, to adopt constitutions modeled on that of the ABS. Nevertheless, the Society faced the same challenge as the Constitutional delegates: procuring unity without stifling the independence of the agents and auxiliaries through whom they were able to express unity. In terms of the structure of the ABS, hierarchy could extend only so far: realizing that their plan for national distribution could best be accomplished through paid agents and auxiliaries, the Society's directors depended on decentralized, semi-autonomous means for the instrumentation of a unified, centralized identity (the Christian nation). Peter Wosh's Spreading the Word, while primarily a history of the ABS, is probably the best account of Bible distribution in the period.

16 Rather than anomalies, the commercial success of Harper's Illustrated Bible (1846) and the impact of Joseph Smith's Book of Mormon (1830) suggest the tremendous appeal that was becoming associated with having one's own distinct version of the Bible. Philip Barlow records it as a matter of fact that "the growing prestige of the Holy Book, as interpreted by oneself, reached its apex in the middle years of the nineteenth century." We can better gauge the height of that apex by noting that before the 1840 s, new translations or revisions of the KJV were all but non-existent in America. Before the Revolution, only a handful of partial translations were made, typically Psalters; the only two full translations in the same period were into foreign languages (the 1663 Eliot Indian Bible and the 1743 German Saur Bible). The tide began to turn slowly with six new English versions and translations made between 1800 and 1830. The deluge began at that point and continued through the Civil War, averaging one new version or translation every two years. Through the $1820 \mathrm{~s}$, the focus had been on distributing copies of the Authorized Version rather than on making a new version on one's own authority. However, suddenly in the 1840 s and 1850 s, one finds almost as many translations of the Bible (either one or both Testaments) as there were individuals who were able, or thought themselves able, to make their own translation. A translator might not even have deemed knowledge of Hebrew or Greek necessary, relying merely on inspiration; many thought revision of the English $\mathrm{KJV}$ in itself was 
sufficient. In terms that reflect the centrality of the problematic of the one and the many to American consciousness, the attraction of private versions of the Bible derives from what one critic has called "an already strong reverence [in America] for unmediated scripture" (Philip L. Barlow, Mormons and the Bible: The Place of the Latter-day Saints in American Religion [New York: Oxford University Press, 1991], 7-8). Fuller accounts of the translation history are given by Harry M. Orlinsky and Robert G. Bratcher, $A$ History of Bible Translation in America and the North American Contribution (Atlanta: Scholars Press, 1991), and Paris Marion Simms, The Bible in America: Versions that Have Played Their Part in the Making of the Republic (New York: WilsonErickson, 1936), an older but nonetheless authoritative work.

17 In the fourth century A.D., Jerome would follow the same practice in his Vulgate translation of the Septuagint. Given Campbell's passion for going back to the original text and recovering what he considered to be the original meaning, it is unsurprising that he, along with Barton Stone and his own father, Thomas, were founders of the Restoration Movement, an anti-denominational, anti-dogmatic group which included the Disciples of Christ and was dedicated to the purity of Christian text and tradition alike.

18 The disputes between Baptists and other sects in these Bible Societies, and among the Baptists themselves, present at least two notions of religious community (that is, of religiously-informed social formation): a differentiated, sovereign sect (comparable to Whitman's "poetics of . . . embodiment") or a non-sectarian whole (comparable to Whitman's "poetics of merger"); see Karen Sánchez-Eppler, "To Stand Between," 924. Details of the ABS's role in the immersionist controversy are available in Peter Wosh, Spreading the Word, 118-150; Roland H. Worth, Jr., Bible Translations: A History through Source Documents (Jefferson, NC: McFarland \& Co., 1992), 152-160; and Orlinsky and Bratcher, History of Bible Translation, 48-86 passim.

19 Whitman's New Bible meant to unify disparates (disenfranchised persons) in a way that no institutionally sanctioned document like the Bible or the Constitution had, in a way that churches and governments could not, dependent as they are on the delegation of power and the reservation of identity - that is, on the hierarchical management of the representation of persons. But since the transformation of social structure was to occur through a text (Leaves), mediation could not be done away with entirely.

20 Whitman, Leaves of Grass: Facsimile Edition of the 1860 Text, ed. Roy Harvey Pearce (Ithaca: Cornell University Press, 1961), 452, 451. Following the practice of the 1860 edition, I have sometimes referred to lines from "So Long!" by the verse markings Whitman gave the poem in that particular text, the marginal numbers that set off each sentence of the poem, instead of the sections that characterize other editions of Leaves. The 1860 variants for "So Long!" are also available in Whitman, Leaves of Grass: $A$ Textual Variorum of the Printed Poems, ed. Sculley Bradley, Harold W. Blodgett, Arthur Golden, and William White, 3 vols. (New York: New York University Press, 1980), 3:452-458.

21 Whitman, Leaves of Grass: Facsimile Edition of the 1860 Text, 456. Whitman later underscored the idea of translation evoked in verse 14 ("I announce an old age that shall lightly and joyfully meet its translation" [454]) by adding the following between the third and fourth lines of the 1860 version: "I receive now again of my many translations, from my avataras ascending, while others doubtless await me" (LG 506).

22 Though often commented upon, the disembodiment/immediacy claim of Whitman's poetry is seldom gotten right, I think. Terry Mulcaire ("Publishing Intimacy in Leaves of Grass," ELH 60 [1993]: 471-501) gives a Marxist reading of the 
Whitmanian construction of the relation between book, body, poet, and public-a reading which, theoretical differences aside, insists as I do that Leaves does not simply offer moments of transcendence and immediacy but rather challenges us to comprehend what I have called the constitutive tension between union and disunion, between generality and particularity or the one and the many. In Mulcaire's terms (which owe much to Foucault), "[t]he cultural distinctions Leaves asks us to make, then, are not between repression and alienation on the one hand and freedom and immediacy on the other but between different linkages of repression and alienation on the one hand and freedom and immediacy on the other" (495; emphasis added).

\section{Whitman, Leaves of Grass: Facsimile Edition of the 1860 Text, 455; LG 34.}

24 The other relevant moment also occurs in the 1860 edition. "Scented Herbage of My Breast" is often read as a rejection of the "show of appearance," or the "[e]mblematic" meaning of the leaves of grass, which are "capricious" because rather than telling what they mean they "mask" the "real reality" they are meant to convey. Rather than a refutation of the signs that cannot be relied upon to "tell in [their] own way of the heart that is under" them, "Scented Herbage" marks a discovery which Whitman develops more fully in the later poem: namely, that "real reality" cannot be made immediate, that "death and love" "hide in these shifting forms of life, for reasons" ( $L G 113-115)$. One of those reasons, I would argue, is the necessarily mediated character of representation, the sacrifices in personhood that are required, paradoxically, to expand the category of person, to extend it in any one direction.

25 Whitman, Leaves of Grass: Facsimile Edition of the 1860 Text, 454. "Old age" was subsequently altered to "end," a word that better stresses the paradox of an end that is also a beginning in another register, a translation, and thus not an end, or a death, in its original register.

26 As W. V. Quine has noted, because no word has an exact foreign equivalent, "uniquely correct translations" do not exist (The Oxford Companion to Philosophy, ed. Ted Honderich [Oxford: Oxford University Press, 1995], 879).

27 Whitman, Leaves of Grass: Facsimile Edition of the 1860 Text, 454, 455, 453.

28 Ibid., 455.

29 Whitman, "Scented Herbage of My Breast," LG 114.

30 Focusing on the "Children of Adam" and "Calamus" clusters, Stefanelli argues that Whitman's "New Bible" is meant to counteract the Bible's vilification of sexuality and transgression: "Whitman reshapes the biblical pattern in order to people his poems with contemporary children of Adam who have interiorized their parents' experiences and live through them with a different attitude, thus transforming sin into a new consciousness of sexuality and nature. A centrifugal movement away from the Biblical text takes place in Whitman's poems, which is the counterpart of the centripetal forces supporting unity in Genesis" (173-174). I would argue, however, that rather than moving in strictly one direction (centrifugal, foundational), the 1860 Leaves moves in two contrary directions (centripetal and centrifugal, supplementary and foundational), as intent on establishing itself as liturgy as it is in refuting the authoritative and institutional status of liturgical texts.

31 Whitman, Leaves of Grass: Facsimile Edition of the 1860 Text, 454.

32 For examples of the slippage between the bodily and the linguistic in Whitman's use of "translate" and "translation," see "Song of Myself," Section 6: "I wish I could translate the hints about the dead young men and women" ( $L G 34$ ); "Song of My- 
self," Section 21: "I am the poet of the Body and I am the poet of the Soul ... / The first I graft and increase upon myself, the latter I translate into a new tongue" ( $L G 48$ ); and "Song of the Answerer": "He resolves all tongues into his own and bestows it upon men, and any man translates, and any man translates himself also" ( $L G 168)$.

33 Whitman, Leaves of Grass: Facsimile Edition of the 1860 Text, 455, 454.

34 Ibid., 419.

35 Whitman, "Chants Democratic," Leaves of Grass: Facsimile Edition of the 1860 Text, 189-190. In the 1867 edition, Whitman re-titled this poem "Mediums," the title it retains in $L G 480-481$. 